\title{
Derrotar o imobilismo para sair da barbárie cultural
}

\author{
José Marques de Melo
}

\section{SciELO Books / SciELO Livros / SciELO Libros}

MELO, JM. Cidadania glocal, identidade nordestina: ética da comunicação na era da internet [online]. Campina Grande: EDUEPB; Latus, 2011. 108 p. ISBN 978-85-63984-07-4. Available from SciELO Books $<\underline{\text { http: } / / \text { books.scielo.org }>\text {. }}$

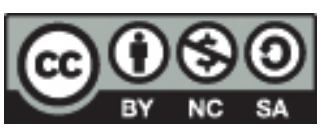

All the contents of this work, except where otherwise noted, is licensed under a Creative Commons Attribution-Non Commercial-ShareAlike 3.0 Unported.

Todo o conteúdo deste trabalho, exceto quando houver ressalva, é publicado sob a licença Creative Commons Atribuição Uso Não Comercial - Partilha nos Mesmos Termos 3.0 Não adaptada.

Todo el contenido de esta obra, excepto donde se indique lo contrario, está bajo licencia de la licencia Creative Commons Reconocimento-NoComercial-CompartirIgual 3.0 Unported. 


\section{Derrotar o imobilismo para sair da barbárie cultural ${ }^{6}$}

Dois sentimentos irrigam minh `alma neste momento solene: gratidão e compromisso.

Gratidão pela generosidade dos colegas que tomaram a iniciativa, dos colegiados e das autoridades que endossaram a homenagem, bem como do público aqui presente, convalidando o ritual acadêmico.

Compromisso pela expectativa decorrente da honraria que me é concedida, cujo significado parece refletir menos o clichê hollywoodiano do happy end, sugerindo o "repouso do guerreiro" e muito mais a metáfora neorealista da cinecitá, proclamando o "adeus às

6 Discurso proferido em São Luis, na noite de 8 de abril de 2010, na solenidade de outorga do título de Doutor Honoris Causa pela Universidade Federal do Maranhão. 
armas", sem contudo renunciar à vigilância cidadã, porque a "luta continua".

Sinto-me gratificado e endividado.

Gratificado pelo carinho, respeito e admiração com que venho sendo distinguido pela comunidade acadêmica maranhense. Liderando a equipe da Universidade de São Paulo que ajudou a implantar o curso de comunicação desta universidade, aqui estive, nos idos de 70, para ensinar e aconselhar, mas também para aprender e conhecer.

Endividado com os gestores de futuras iniciativas, reafirmo que estarei sempre disponível, na medida das minhas forças e no limite 68 da minha competência, para fortalecer a vanguarda das ciências da comunicação que aqui está se constituindo.

Ainda recentemente, tive a alegria de incluir dois maranhenses emblemáticos num projeto de resgate da memória do jornalismo brasileiro. E ambos corresponderam à minha convocação, inscrevendo figuras estaduais na galeria dos personagens que fizeram História nacional.

O veterano Sebastião Jorge convenceu-me a destacar símbolos representativos de diferentes conjunturas: o irônico João Francisco Lisboa e o boêmio Amaral Raposo. 
O emergente José Ferreira Junior contribuiu para difundir no panorama nacional a versatilidade de Aluízio de Azevedo, focalizando seu desempenho como folhetinista de sucesso.

Ao evocar esses ícones da cultura maranhense - Lisboa, Raposo e Azevedo -, que perfilaram papéis de relevo em sua época, quero, na verdade, emular as novas gerações a neles se inspirar, resistindo aos apelos sedutores das ondas que, de tempos em tempos, invadem a nossa academia. Criando laços de dependência intelectual, tais modismos anulam nossa capacidade de pensar com a própria cabeça, nossa predisposição para andar com as nossas pernas, nossa consciência de agir soberanamente.

Não pretendo de forma alguma incentivar comportamentos típicos de insularidade e xenofobia. Ao contrário, defendo a livre circulação das ideias, de modo a garantir a pluralidade de visões e a diversidade de opções. Mas não abdico do direito à autodeterminação e do dever de projetar nossas identidades no cenário mundial.

É bem verdade que a nossa tradição intelectual é caudatária do pensamento europeu, que, adaptado ao ambiente nacional, produziu um modo de pensar mestiço e um modo de agir consentâneo com as nossas aspirações caboclas. 
Percebo, contudo, nas novas vanguardas, principalmente aquelas que usufruíram formação pós-graduada no além mar, uma forte aderência aos modelos de pensamento hegemônicos nas matrizes em que se nutriram intelectualmente. Muitas dessas lideranças mimetizam os seus mestres e reproduzem automaticamente suas teses, sem submetê-las previamente à crítica dos colégios invisíveis atuantes no território nacional. Sem testar a aculturação desses referenciais ao nosso ethos , exatamente como fizeram de forma criteriosa os nossos pioneiros das ciências humanas, entre eles Gilberto Freyre, Anísio Teixeira, Celso Furtado ou como procederam os seus conti70 nuadores: Darcy Ribeiro, Manuel Correia de Andrade ou Roberto DaMatta.

Nosso campo do conhecimento vive, contemporaneamente, um impasse decisivo que não convém postergar. Trata-se de optar entre a valorização e o fortalecimento dos modelos híbridos, resultantes da mestiçagem processada entre as matrizes forâneas e as demandas ibero-americanas ou a assimilação a-crítica dos postulados teóricos imported from Washington, Moscou, Roma, Londres, Paris ou Berlim.

Quando, há 40 anos, aqui estive pela primeira vez, encontrei um ambiente acadêmico efervescente, ainda impregnado da forte tradição literária maranhense. O jornalismo local 
era praticamente uma extensão das letras clássicas e vernáculas cultivadas nos liceus e grêmios de vanguarda.

A vida pacata de São Luis representava excelente campo de observação de um tempo finito e de cenários memoráveis, para um grupo de professores acostumados ao cosmopolitismo paulistano, quase completamente imersos na cultura de massa. A mídia aqui existente ainda era mediada pelas conversações interpessoais nos pontos de aglomeração coletiva e as correntes de opinião pública eram influenciadas pelas interpretações comunitárias dos agentes folkcomunicacionais tão bem descritos por Luiz Beltrão.

Hoje o panorama mudou completamente, verificando-se a integração gradativa ao universo globalizado, embora persistam traços marcantes das identidades regionais. Constitui, a meu ver, tarefa urgente a desafiar a inteligência da geração que povoa as escolas de comunicação, nesse limiar do século XXI, entender como se deu uma transformação tão brusca e quais os impactos provocados na vida da sociedade, na configuração política e no tecido cultural maranhenses.

Não pretendo de forma alguma induzir os meus jovens colegas a debruçar-se sobre o passado, para revivê-lo saudosamente. O que Ihes proponho é o conhecimento crítico de um espaço ainda em mutação, onde passado e 
presente convivem dialeticamente, no sentido de resgatar elementos capazes de preservação seletiva e de renovação criativa.

Dessa maneira, estaremos produzindo conhecimento comunicacional sintonizado com as nossas raízes, neutralizando a rendição incondicional aos padrões disseminados por livros-textos fabricados nos centros hegemônicos e validados pelos comitês universitários compungidos a assumir diretrizes equivocadas oriundas das agências nacionais que monitoram o ensino e a pesquisa.

Temos o dever de batalhar por uma academia soberana, que não se isole da comunidade 72 internacional, contribuindo para o desenvolvimento de outra sociedade, justa, fraterna e solidária, mas fiel ao patrimônio cognitivo construído pelas lideranças que nos precederam. Alguns desses colegas sofreram as agruras do exílio ou experimentaram as asperezas das discriminações internas, sem capitular perante a sedução engenhosa dos que manipulam o aparato estatal ou movem as engrenagens da indústria cultural.

Somos um país estigmatizado pela cultura do silêncio, reflexo do mutismo dos cidadãos e da apatia da coletividade. Temos uma população formada por vastos contingentes famintos de leitura, sedentos de cultura e demandantes de participação. O que fazer para superar esse 
dramático impasse político-cultural, ultrapassando a barbárie e ingressando na civilização?

Trata-se de uma dívida histórica que precisamos saldar com o nosso povo, construindo um futuro alentador. Do contrário, estamos condenados a permanecer na periferia da chamada sociedade do conhecimento, bestificados diante dos que se arvoram mandatários da vontade coletiva, como procederam as testemunhas oculares da proclamação da nossa República.

Repito: a homenagem que me presta a Universidade Federal do Maranhão, nesta bela solenidade, eu a interpreto como um apelo metafórico para não "pendurar as chuteiras".

Não desejo imitar o caminho escolhido por vários colegas da minha geração, hoje confortavelmente instalados na tribuna de honra dos estádios. Quero calçá-las, para reforçar, ainda que na retaguarda pensante, o time que pode derrotar o imobilismo e a inércia dominantes na vida intelectual brasileira.

Este é o compromisso que assumo perante esta comunidade, no momento em que dela recebo a afetividade, o incentivo e o reconhecimento.

Vamos à luta! Vamos recorrer às armas do conhecimento! Vamos convencer pela força da argumentação! Vamos triunfar pelo ardor da nossa paixão! 